\title{
A limitation of Chase's proposal for safe doubling of ventilator capacity
}

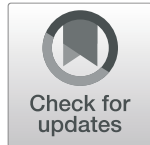

Ross Freebairn ${ }^{1,2^{*}}$ (D) and Michael Park ${ }^{1}$

Letter:

We read with interest the description by Chase and colleagues of a system to provide an "in series" rather than "in parallel" sharing of a single ventilator between two patients [1]. Their suggestion is that this is a "last resort technique" that may be useful during the COVID-19 pandemic surge. In contradistinction to other "shared ventilation" systems, Chase's design permits individual adjustments for patients' compliance and PEEP [2]. However, using the system described by Chase, every second breath is delivered to each patient. This results in an inspiration time limited to less than $50 \%$ of the respiratory cycle time, even if the ventilator set expiration time is minimized [3]. Several ventilators further limit inspiratory time to $80 \%$ of cycle time, meaning the longest inspiratory time would be an I:E ratio of $1: 1.5$ [4].

COVID-19 respiratory failure is characterized by severe hypoxemia, often with near normal compliance, and frequently resistant to PEEP and recruitment maneuvers [5]. One additional strategy available to increase oxygenation is to increase inspiratory time, which allows more distribution of fresh gas to slow filling alveoli and raises the mean alveolar pressure. The Chase apparatus's inability to provide reverse ratio or even 1:1 ventilation is an important limitation in severe hypoxemia respiratory failure that may reduce its utility in a COVID-19 crisis.

\section{Acknowledgements}

Nil

Authors' contributions

Equal contribution to the writing of the letter. The authors read and approved the final manuscript.

\footnotetext{
* Correspondence: ross.freebairn@xtra.co.nz

'Hawke's Bay Hospital, Omahu Road, Hastings 4221, New Zealand

University of Otago, Dunedin, New Zealand
}

Funding

Nil

Availability of data and materials

Not applicable

Ethics approval and consent to participate

Not applicable

\section{Consent for publication}

Not applicable

\section{Competing interests \\ The authors have no competing interests.}

Received: 31 July 2020 Accepted: 9 August 2020

Published online: 18 August 2020

\section{References}

1. Chase JG, Chiew YS, Lambermont B, Morimont P, Shaw GM, Desaive T. Safe doubling of ventilator capacity: a last resort proposal for last resorts. Crit Care. 2020;24(1):222.

2. Epstein D, Hoffman Y, Dahoud G, Raz A, Miller A. Simultaneous ventilation of two simulated ARDS patients in COVID-19 pandemic. Critical Care. 2020; 24(1):214.

3. Puritan Bennett 840 Ventilator [technical data ]. [Available from: https:// www.medtronic.com/content/dam/covidien/library/us/en/product/acutecare-ventilation/puritan-bennett-980-ventilator-system-tech-specifications. pdf. Accessed 24 July 2020.

4. Hamilton Medical C6 Ventilator [technical data]. [Available from: https:// www.hamilton-medical.com/dam/jcr:0d8ebdcc-55d5-4604-86cc-e98d3 ade7ead/HAMILTON-C6-tech-specs-en-689596.02.pdf. Accessed 24 July 2020.

5. Gattinoni L, Chiumello D, Rossi S. COVID-19 pneumonia: ARDS or not? Crit Care. 2020;24(1):154.

\section{Publisher's Note}

Springer Nature remains neutral with regard to jurisdictional claims in published maps and institutional affiliations.

C C The Author(s). 2020 Open Access This article is licensed under a Creative Commons Attribution 4.0 International License, which permits use, sharing, adaptation, distribution and reproduction in any medium or format, as long as you give appropriate credit to the original author(s) and the source, provide a link to the Creative Commons licence, and indicate if changes were made. The images or other third party material in this article are included in the article's Creative Commons licence, unless indicated otherwise in a credit line to the material. If material is not included in the article's Creative Commons licence and your intended use is not permitted by statutory regulation or exceeds the permitted use, you will need to obtain permission directly from the copyright holder. To view a copy of this licence, visit http://creativecommons.org/licenses/by/4.0/ The Creative Commons Public Domain Dedication waiver (http://creativecommons.org/publicdomain/zero/1.0/) applies to the data made available in this article, unless otherwise stated in a credit line to the data. 